\title{
Towards a mathematical model of the cAMP pathway in $S$.
} cerevisiae

\author{
Thomas Williamson*1, Frank Bruggemann², Douglas Kell ${ }^{2}$ and \\ Lubomira Stateva ${ }^{1}$
}

Address: ${ }^{1}$ Faculty of Life Scienes, Michael Smith Building, Univeristy of Manchester, Manchester, UK and ${ }^{2}$ Manchester Interdisciplinary Biocentre, University of Manchester, Manchester, UK

Email: Thomas Williamson* - thomas.williamson@postgrad.manchester.ac.uk

* Corresponding author

from BioSysBio 2007: Systems Biology, Bioinformatics and Synthetic Biology

Manchester, UK. II-13 January 2007

Published: 8 May 2007

BMC Systems Biology 2007, I(Suppl I):PI8 doi:10.1 186/I752-0509-I-SI-PI8

This abstract is available from: http://www.biomedcentral.com/I752-0509/I?issue=SI

(C) 2007 Williamson et al; licensee BioMed Central Ltd.

\section{Background}

The small, diffusible molecule cAMP plays a key signalling role in almost all organisms. In S. cerevisiae, cAMP is synthesized by adenylate cyclase [1], and hydrolyzed by the phosphodiesterases Pde1p and Pde2p [2,3]. The only function of cAMP in yeast is to activate PKA (Protein Kinase A). A molecule of PKA is a tetramer consisting of two catalytic (C) and two regulatory (R) subunits. Cyclic $\mathrm{AMP}$ binds to the $\mathrm{R}$ subunit, allowing its dissociation from $\mathrm{C}$, allowing $\mathrm{C}$ to become catalytically active. PKA is believed to activate Pde1p [4], as well as indirectly inhibit the activity of adenylate cyclase [5]. We have created two mathematical models (one simplified and one detailed) in order to better understand the mechanisms of PKA activation. We have also created a model to investigate the complete cAMP pathway.

\section{Results}

The PKA models are able to behave appropriately when the cAMP level is altered, giving an increased concentra-
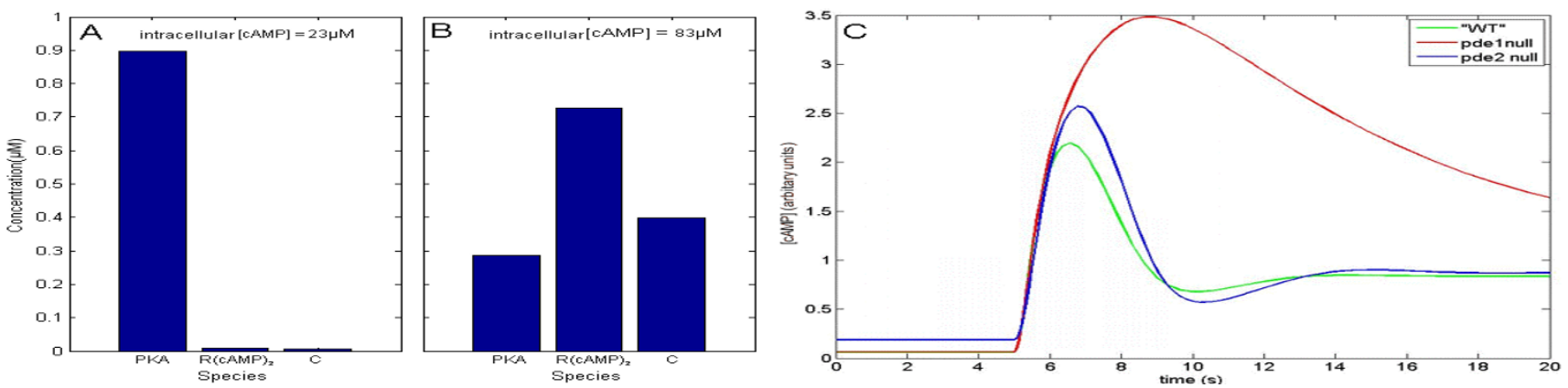

Figure I

Species concentrations of the detailed PKA model under low (A) and high (B) cAMP concentration. C: cAMP levels of model mutants. Glucose concentration is increased after five seconds. 
tion of free catalytic subunit (see Figure 1). In the wild type complete pathway model a "spike" of cAMP is observed after glucose addition. The cAMP level oscillates before reaching a steady state. The spike has a higher peak in the pde1 $\Delta$ mutant (see Figure 1 ).

\section{Conclusion}

The models of PKA activation can reproduce events seen in vivo, but the detailed model also allows for concentrations of intermediates to be predicted. This could give insights into the mechanism by which PKA activation is regulated. The complete pathway model can reproduce phosphodiesterase knockout mutant phenotypes seen in vivo [4], as well as predicting that the cAMP level oscillates before reaching a steady-state. Further analysis and development of these models should give further insights into the cAMP pathway in yeast.

\section{References}

I. Kataoka T, Broek D, Wigler M: DNA sequence and characterization of the $S$. cerevisiae gene encoding adenylate cyclase. Cell 1985, 43:493-505.

2. Nikawa J, Sass P, Wigler M: Cloning and characterization of the low-affinity cyclic AMP phosphodiesterase gene of Saccharomyces cerevisiae. Mol Cell Biol 1987, 7:3629-3636.

3. Sass P, Field J, Nikawa J, Toda T, Wigler M: Cloning and characterization of the high-affinity CAMP phosphodiesterase of Saccharomyces cerevisiae. Proc Natl Acad Sci USA 1986, 83:9303-9307.

4. Ma P, Wera S, Van Dijck P, Thevelein JM: The PDEI-encoded lowaffinity phosphodiesterase in the yeast Saccharomyces cerevisiae has a specific function in controlling agonist-induced cAMP signaling. Mol Biol Cell 1999, 10:91-104.

5. Gross E, Goldberg D, Levitzki A: Phosphorylation of the S. cerevisiae Cdc25 in response to glucose results in its dissociation from Ras. Nature 1992, 360:762-765.
Publish with Biomed Central and every scientist can read your work free of charge

"BioMed Central will be the most significant development for disseminating the results of biomedical research in our lifetime. "

Sir Paul Nurse, Cancer Research UK

Your research papers will be:

- available free of charge to the entire biomedical community

- peer reviewed and published immediately upon acceptance

- cited in PubMed and archived on PubMed Central

- yours - you keep the copyright

Submit your manuscript here:

http://www.biomedcentral.com/info/publishing_adv.asp 